\title{
Assessing the organizational climate for translational research with a new survey tool
}

Arno Simons $^{1 *}$, Nico Riedel ${ }^{2}$, Ulf Toelch ${ }^{2}$, Barbara Hendriks ${ }^{3}$, Stephanie Müller-Ohlraun ${ }^{2}$, Lisa Liebenau ${ }^{2}$, Jens Ambrasat ${ }^{1}$, Ulrich Dirnag ${ }^{2,4}$, Martin Reinhart ${ }^{3}$

${ }^{1}$ German Centre for Higher Education Research and Science Studies (DZHW), Berlin, Germany.

${ }^{2}$ QUEST Center for Transforming Biomedical Research, Berlin Institute of Health, Berlin, Germany.

${ }^{3}$ Humboldt-Universität zu Berlin, Department of Social Sciences, Berlin, Germany.

${ }^{4}$ Charité - Universitätsmedizin Berlin, Germany.

${ }^{5}$ Corresponding author

Dr. Arno Simons/ DZHW

Schützenstraße 6A

10117 Berlin

Email:ssimons@dzhw.eu

Tel: +49 $302064177-50$

Fax: +49 30 2064177-99 


\section{Assessing the organizational climate for}

\section{translational research with a new survey tool}

\section{Abstract}

Promoting biomedical translation from bench to bedside and back in organizational settings is a central challenge for research managers and policymakers. For this, organizational leaders need to assess baseline conditions, identify areas needing improvement, and to judge the impact of specific initiatives to sustain or improve translational research practices at their institutions. Currently, there is a lack of such an assessment tool addressing the specific context of translational biomedical research. To close this gap, we have developed and tested a new survey for assessing the organizational climate for translational research. This self-assessment tool measures employees' perceptions of translational climate and underlying research practices in organizational environments and builds on the established Survey of Organizational Research Climate. Having implemented the new survey in practice, we show that scientists at a large university hospital (Charité Berlin) perceive translation as a central and important component of their work. Importantly, local resources and direct support are main contributing factors for the practical implementation of translation into their own research practice. We identify and discuss potential leverage points for an improvement of research climate to foster successful translational research.

\section{Introduction}

Promoting biomedical translation from bench to bedside and back in organizational settings is a central challenge for research managers and policymakers. Several attempts have been made to model translational research as a linear, bidirectional, or circular process [1-5], and it has been suggested that framing translation one way or another will have practical implications, e.g. on 'how we train the next generation of researchers' [6]. It has also become clear that supporting translational research is more than a matter of disseminating evidence about best practices to researchers and practitioners and expecting instant improvement. Instead, organizational leaders tasked with 
improving translational research at their institutions understand that translational practices are diverse, highly context specific, and dependent on organizational cultures in support of translation [6-10].

So far, no tool exists that would allow organizational leaders to assess baseline conditions, identify areas needing improvement, and to judge the impact of specific initiatives to sustain or improve translational research practices at their institutions. To close this gap, we have developed and tested a survey for assessing the organizational climate for translational research. This Survey of Translational Research Climate (STRC) can be used as a self-assessment tool to assess employees' perceptions of translational climate and potentially underlying research practices and conditions in organizational environments. Aggregated responses within meaningful organizational units provides a measure of group-level perceptions of environmental conditions, i.e. the 'organizational climate', for translational research.

Organizational researchers define organizational climate as 'the shared meaning organizational members attach to the events, policies, practices, and procedures they experience and the behaviors they see being rewarded, supported, and expected' [11]. Organizational climate is conceptually distinct from organizational culture, the latter of which is a 'deeper-level construct' [11]. Organizational culture puts the focus on organizational members' perceptions of their organizational environment, while organizational climate puts the focus on judgements and values [12]. However, the two concepts are intimately connected: organizational climate 'is both the manifestation of culture....and the data on which culture comes to be inferred and understood' [13].

In developing the STRC, we built on the Survey of Organizational Research Climate (SORC) that assesses the organizational climate with respect to research integrity. The STRC follows the general structure of the SORC, a validated questionnaire, but rephrases the questions in terms of translational climate.

As in the original SORC, the STRC distinguishes between two levels of analysis: 1) the immediate research environment (individuals' primary subunit, such as research group or institute), and 2) the organization as a whole. Consequently, we define translational research climate as the product of individual and group perceptions about their organizational unit - whether institution, division, department, center, program, or work group - in terms of how it values, is committed to, and administers its programs in ways that encourage the translation of results between basic research, clinical research, and practice. 
This paper reports a first assessment of this newly developed instrument that was implemented at one of Europe's largest university hospitals, the Charité - Universitätsmedizin Berlin, and compared against results from the original SORC.

\section{Methods}

\section{Measures}

The full questionnaire can be found in supplemental File 1. Here we describe its component parts.

\section{Translational research climate}

To assess the climate for translational research, we have developed a standardized questionnaire, modeled after the SORC, whose items fall into two groups: a) six items assessing the organizational climate for translational research practices on the institutional level (section $2 \mathrm{~A}$ of the survey), b) twelve items assessing the organizational climate for translational research practices on the level of one's immediate research environment (section 2B of the survey). Each item asks about the respondent's perception of a particular aspect of the translational research climate in the organization as a whole or in the respondent's immediate research environment, respectively, e.g. 'How committed are the senior administrators at your institution (e.g. deans, executive board) to supporting translational research?'. Respondents rated items on a 5 point scale: 1) Not at All, 2) Somewhat, 3) Moderately, 4) Very, and 5) Completely. To avoid forcing respondents to rate items, we offered two more response options: 6) No Basis for Judging, and 7) Prefer not to Disclose.

The selection and formulation of items underwent a two-step process. First, we checked for all original SORC items if they can be adapted for our purpose by replacing key formulations, e.g. 'responsible research' by 'translational research'. Some SORC items had to be dropped, since they would not make sense when applied to translational research climate, e.g. items about research misconduct. Second, we discussed our list of items among our project group, which included both medical researchers, experts on translational medicine, and social scientists. We then assessed the construct validity with five respondents during a pretest phase. Respondents were of different status (graduate students, post docs, professors), gender, and working at different ends of the bench to bedside continuum (researchers, clinicians, clinician scientists). 


\section{Translational research practices}

We further included a set of 15 items asking about the respondents' self-reported translational research practices (section $2 \mathrm{C}$ of the survey) to be able to relate these to the perceived translational research climate. We constructed these items to reflect six dimensions of translational practices - 1) education, 2) communication, 3) publication, 4) collaboration, 5) career path, 6) overall. We identified these dimensions using qualitative data (literature review and interviews with 78 researchers, clinicians, and clinician scientists) from a previous research project on translation [910]. The items were discussed and tested, together with the translational climate items, in our project group and in our pretest.

\section{Research integrity climate}

We also included the complete set of research integrity climate items of the original SORC - 11 items for assessing institutional climate (section $1 \mathrm{~A}$ of the survey) and 21 items for assessing the climate of the immediate research environment (section 1B of the survey). This allowed us to investigate whether constructs in our translational research climate survey (STRC) were distinct from established constructs of research integrity climate (SORC).

\section{Other measures}

Section 3 of the survey included questions about the professional status at the institution, primary departmental affiliation, enrollment in a doctoral program, number of years working in research, whether one's research is preclinical, clinical, or both, professional areas of interest, size of the immediate research environment, gender, and year of birth.

For sections 1 and 2 in our survey, we also included a final free text question to allow the respondent to make further comments, e.g. 'Are there any other things about your experience with translational research practices at your institution that you would like to tell and about which we have not already asked?'

\section{Data collection}

Our study was approved by the Charité's ethics committee (ethics vote number EA1/184/17) as well as the Data Protection Office and the staff council and was conducted as an anonymous web-based survey. For the use of the SORC, a license agreement was signed. The Charité administration helped us to identify all researchers and doctoral students working at the institution, 7264 individuals in total. We generated an equal number of electronical tokens 
and provided these to the study center's administration, the latter of which created a linking table, assigning tokens to email addresses, and sent the researchers invitation emails with a token-unique-hyperlink to the online survey, followed by a reminder two weeks later. The emails were sent in the name of the Dean of the Charité. As an incentive to participate, per participant $2 €$ were donated to one of two preselected non-governmental organizations (NGOs) working in the field of health care, from which participants could choose after having finished the questionnaire. This study was preregistered on OSF (https://osf.io/qak8e/). The survey was online for a period of four weeks during February and March 2018. Of all 7264 invitees, 1095 opened the survey for at least one second, 969 answered at least the first question, 602 completed at least section 1 (the SORC), 533 completed at least section 2B (the STRC), 523 completed at least section 2C (self-reported translational research practices). 521 invitees completed the whole questionnaire including all status and demographic items, resulting in a response rate of $7 \%$.

A non-response analysis conducted after completion of the survey and sent to all invitees returned that a number of participants were interrupted during filling the survey but were not aware that they could continue later on or simply forgot to do so. Others were discouraged by the length of the questionnaire.

To guarantee the anonymity of the respondents, none of the authors had access to the study center's linking table, assigning tokens to email addresses, and the study center, in turn, had no access to the raw data, linking tokens to individual responses. Three of the authors (AS, BH, MR) deleted the token column and further pseudonymized responses by aggregating birth years into 5 -year intervals and omitting the answers of the free text questions. The resulting dataset and the corresponding codebook are available from the OSF database at

\section{https://doi.org/10.17605/OSF.IO/QAK8E.}

\section{Statistical analysis}

When analyzing our data, we investigated two types of relationships, R1 and R2, as illustrated in Fig 1. First, we established relevant factors for the STRC. Subsequently, we examined the identified factors for uniqueness with regard to the SORC questionnaire (R1). Finally, we investigated the relationship between the STRC and the items on translational research practice (R2). 
Fig 1. Relations between STRC and SORC. In the analysis of the STRC we focus on examining the overlap of STRC questions and the SORC questions (R1) as well as the relationship between STRC and translational practice questions (R2).

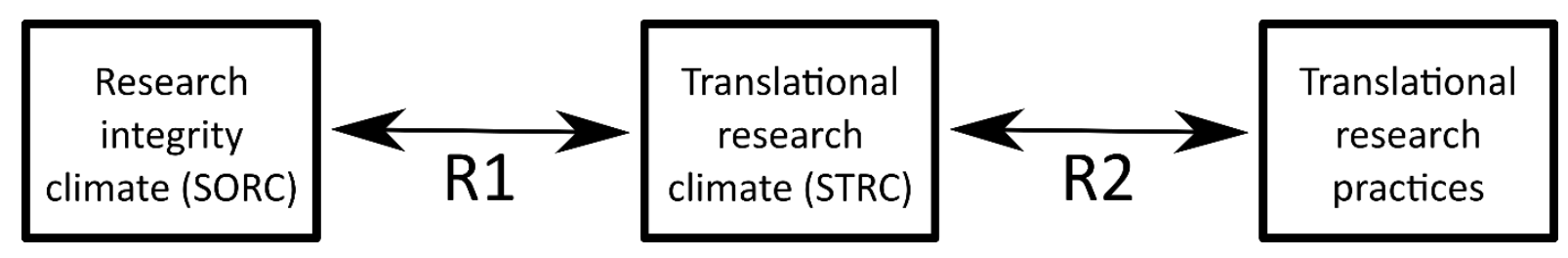

\section{Exploratory and confirmatory factor analysis}

To determine factors that summarize the answers to the STRC on a reduced number of scales we performed an exploratory factor analysis (EFA) on the STRC part of the questionnaire. For this, we followed the methods used for the development of the SORC scales [14].

In summary, we mapped the answers to a numerical scale ranging from 1 ('Not at all') to 5 ('Completely'). We then determined the number of factors by Horn's parallel analysis [15]. The factor analysis was conducted using maximum likelihood estimation under a varimax rotation, which forces the individual items to load primarily on one of the factors. Each item was assigned to the factor for which it had the highest loading. No further modification was done for the factors after the analysis. For this analysis, participants were excluded who did not complete the questionnaire or gave answers 'No basis for judging' or 'Prefer not to disclose' more than $50 \%$ of the time for the STRC part of the questionnaire, leaving the answers of 438 participants for the analysis (i.e. 83 participants with $>50 \%$ 'No basis for judging' or 'Prefer not to disclose' answers for the STRC part).

As we had only one third of the participant responses available as were used for the original SORC validation (438 full responses compared to 1267 responses for SORC), we chose a slightly different approach for the confirmatory factor analysis. Instead of initially splitting the full dataset into two parts, we used the full dataset for the EFA for the initial estimate of the factors. Then the dataset was split into two random parts $n=100$ times. Each time the EFA was repeated on one half of the data to assess the robustness of the factors under different partitioning of the data. A confirmatory factor analysis (CFA) was then performed on the second half of the data, fixing the factors as determined in the EFA on the first half of the data. The average goodness of fit parameters $\left(\chi^{2} / d f\right.$, CFI, RMSEA, SRMR) were calculated for the CFA models to assess the adequacy of the fit. 
Additionally, we analyzed the relationship between the STRC and the SORC by performing an analogous exploratory factor analysis (EFA) on the combined question set of both questionnaires to test if the factor analysis distinguishes the STRC and SORC parts of the questionnaire.

\section{Regression modeling}

Next, we analyzed the relationship between the STRC and the translational research practice questions using a regression analysis.

The following six dimensions of self-reported translational research practices were constructed prior to the conduction of the survey: overall (questions 2C01, 2C02), education (2C03), communication (2C04, 2C09, 2C10), publication $(2 \mathrm{CO}, 2 \mathrm{CO}, 2 \mathrm{C} 07,2 \mathrm{CO})$, collaboration $(2 \mathrm{C} 11,2 \mathrm{C} 12)$, career path $(2 \mathrm{C} 13,2 \mathrm{C} 14)$.

For the STRC questions, we used the factors that we established in the factor analysis. For both the STRC factors and the practice dimensions, we calculated the average scores for each factor/dimension as the mean of the scores for each question belonging to the factor/dimension. The average score was only calculated if participants answered more than $50 \%$ of the questions belonging to the factor/dimension.

To assess the relationship between the STRC factor scores and the practice dimension scores, we fitted a multiple linear regression model for each of the practice dimension using the three STRC factor scores as predictive variables. As the 'career path' dimension consists of two 'yes/no' questions, we fit a logistic regression model in this case. For this we categorized the answers for this practice dimension as follows: a) at least one of the two questions answered 'yes' b) none of the questions answered 'yes'. To account for the many different models that are tested, resulting $p$ values were corrected using the Benjamini Hochberg procedure [16].

The intraclass correlation (ICC) with respect to the institutions centers is calculated for the STRC factors to test if there is a difference in the perception of translational research practices within the surveyed institution.

For easier comparison with the results obtained in a study on the relationship between research integrity climate and practice for the SORC survey [17], we additionally repeated their analysis methods on the STRC (supplemental Table S3). 


\section{Results}

\section{STRC Factors}

To determine into which coherent categories the items of the STRC can be grouped, we performed a factor analysis.

The parallel analysis estimated that four factors are needed for the factor analysis. However, the EFA using four factors yielded one factor mainly determined by one question (2B08: 'How effectively are junior researchers socialized in translational research practices?'). Thus, we decided to use three factors for the EFA instead.

As can be seen in Table 1, whereas factor 1 ('Immediate environment') only loads questions concerning the immediate research environment, factor 2 ('Institution') only loads questions on the institutional level. Factor 3 ('Lack of resources \& pressure') combines four questions that deal with the lack of resources and publishing pressure. For all questions of factor 3, a larger score is inversely coded compared to the other questions, i.e. higher values denote a more negative view of the research environment.

Table 1. Factors obtained with the exploratory factor analysis for the STRC questionnaire. 

environment reflect high values for the translation of research? maintaining high standards of translation in their research? environment communicate high expectations for translational research?

talking with advisees about key principles of translational research? practices?

expectations with respect to making your research useful for safe and effective health measures? proposing, performing, and reporting research in your immediate research environment? for the translation of research? executive board) to supporting translational research? of translation in their research? teach about translational research practices (e.g., lectures, seminars, web-based courses)? 
executive board) communicate high expectations for translational

research?

$2 A 04$

How accessible are individuals with appropriate expertise that you could

2

0.54

ask for advice if you had a question about the translation of your

research?

effect on making your research useful for safe and effective health measures? your research useful for safe and effective health measures? access to material resources such as space, equipment, or technology? access to human resources such as expertise in research design, administrative or technical staff within your immediate research environment?

Questions for each factor are sorted according to factor loadings.

Repeating the EFA on random $50 \%$ subsets of responses yielded a stable estimate of factors. While the factors stayed the same as for the EFA on the full data in 83 of the 100 cases, only one question is shifted between factors in the remaining 17 cases. The CFA applied on the other halves of the responses yielded average goodness of fit parameters that are slightly worse than those obtained for the original SORC $\left(\chi^{2}=283, d f=132, C F I=0.85, R M S E A=\right.$ 0.10$, SRMR $=0.091)$

The average scores for the factors denote mean scores of all items belonging to a factor. The mean is not weighted by the EFA factor loadings, analogously to the SORC questionnaire. The average scores for the STRC factors for our survey responses are reported in Table 2. High values of Cronbach's $\alpha$, especially for the first two factors, demonstrate a good internal consistency of the factors. 
Table 2. Average scores for the STRC factors.

\begin{tabular}{llll} 
& $\begin{array}{l}\text { Immediate } \\
\text { environment }\end{array}$ & Institution & $\begin{array}{l}\text { Lack of resources \& } \\
\text { pressure }\end{array}$ \\
\hline n & 449 & 382 & 402 \\
\hline mean & 3.21 & 3.02 & 2.92 \\
\hline standard deviation & 0.83 & 0.73 & 0.90 \\
\hline Reliability (Cronbach's $\boldsymbol{\alpha}$ ) & 0.91 & & 0.75
\end{tabular}

The first row denotes the number of participants that answered more than 50\% of the questions (not counting answers 'No basis for judging' or 'Prefer not to disclose') for each factor. The internal consistency of the factors is measured by Cronbach's $\alpha$. Note that Lack of resources is inversely coded.

\section{SORC vs. STRC (R1)}

While the mean scores for the original SORC scales were smaller than in the SORC publications, the standard deviations were very similar and the reliability coefficients are only slightly smaller (Table 3) $[18,14]$.

Table 3. Average scores for the original SORC scales.

\begin{tabular}{llllllll} 
& $\begin{array}{l}\text { Integrity } \\
\text { Norms }\end{array}$ & $\begin{array}{l}\text { Integrity } \\
\text { Socialization }\end{array}$ & $\begin{array}{l}\text { Integrity } \\
\text { Inhibitors }\end{array}$ & $\begin{array}{l}\text { Advisor- } \\
\text { Advisee } \\
\text { Relation }\end{array}$ & $\begin{array}{l}\text { Departmental } \\
\text { Expectations }\end{array}$ & $\begin{array}{l}\text { RCR } \\
\text { Resources }\end{array}$ & $\begin{array}{l}\text { Regulatory } \\
\text { Quality }\end{array}$ \\
\hline $\mathbf{n}$ & 471 & 469 & 497 & 509 & 423 & 454 & 398 \\
mean & 3.67 & 3.12 & 2.80 & 3.42 & 3.22 & 2.99 & 3.13 \\
standard & 0.81 & 0.85 & 0.77 & 0.96 & 0.95 & 0.80 & 0.80 \\
deviation & & & & & & & \\
\\
Reliability
\end{tabular}

(Cronbach's $\alpha)$

The first row denotes the number of participants that answered more than 50\% of the questions (not counting answers 'No basis for judging' or 'Prefer not to disclose') for each SORC scale. RCR abbreviates 'responsible conduct of research' 
When combining the STRC and SORC, Horn's parallel analysis estimated that 7 factors are necessary for the factor analysis. The EFA yielded seven factors that separate the two questionnaires well: while there are only SORC questions in factors 1, 3 (except for one STRC question), and 7, there are only STRC questions in factors 2 and 5 (see supplemental Table S1). The STRC factors found in the combined factor analysis directly relate to the factors established for the STRC questionnaire alone: factor 2 in the combined analysis loads the same items as factor 1 in the STRC factor analysis and factor 5 (combined) loads the same items as factor 2 (STRC) except for one item (2A04). Additionally, there are two mixed factors that combine the STRC and SORC questions on the same topic: factor 4 (pressure to publish \& obtain funding) and 6 (insufficient resources).

\section{Relationship STRC and translational research practices (R2)}

To investigate how the STRC factors relate to the different dimensions of translational practice, we performed a multiple linear regression analysis per practice dimension with the STRC factors as predictors.

As shown in Fig 2, the connection is strongest and most consistent for the 'Immediate environment' factor, while the coefficient estimates were smaller for the 'institution' factor and the 'Lack of resources \& pressure'. The largest effect sizes (i.e. regression coefficients) were found between the variables 'Immediate environment' and 'Overall' ( $\beta$ $\left.=0.54, p=9.5 \times 10^{-15}\right)$, 'Immediate environment' and 'Collaboration' $\left(\beta=0.30, p=8.6 \times 10^{-5}\right)$, 'Immediate environment' and 'Communication' $\left(\beta=0.24, p=5.1 \times 10^{-5}\right)$ (supplemental Table S2).

\section{Fig 2: Regression coefficients for the STRC factors and their confidence intervals for all six regression}

models for the different practice dimensions. For the 'Career path' dimension a logistic regression was used, such that this regression coefficient is not directly comparable with the other coefficients. 


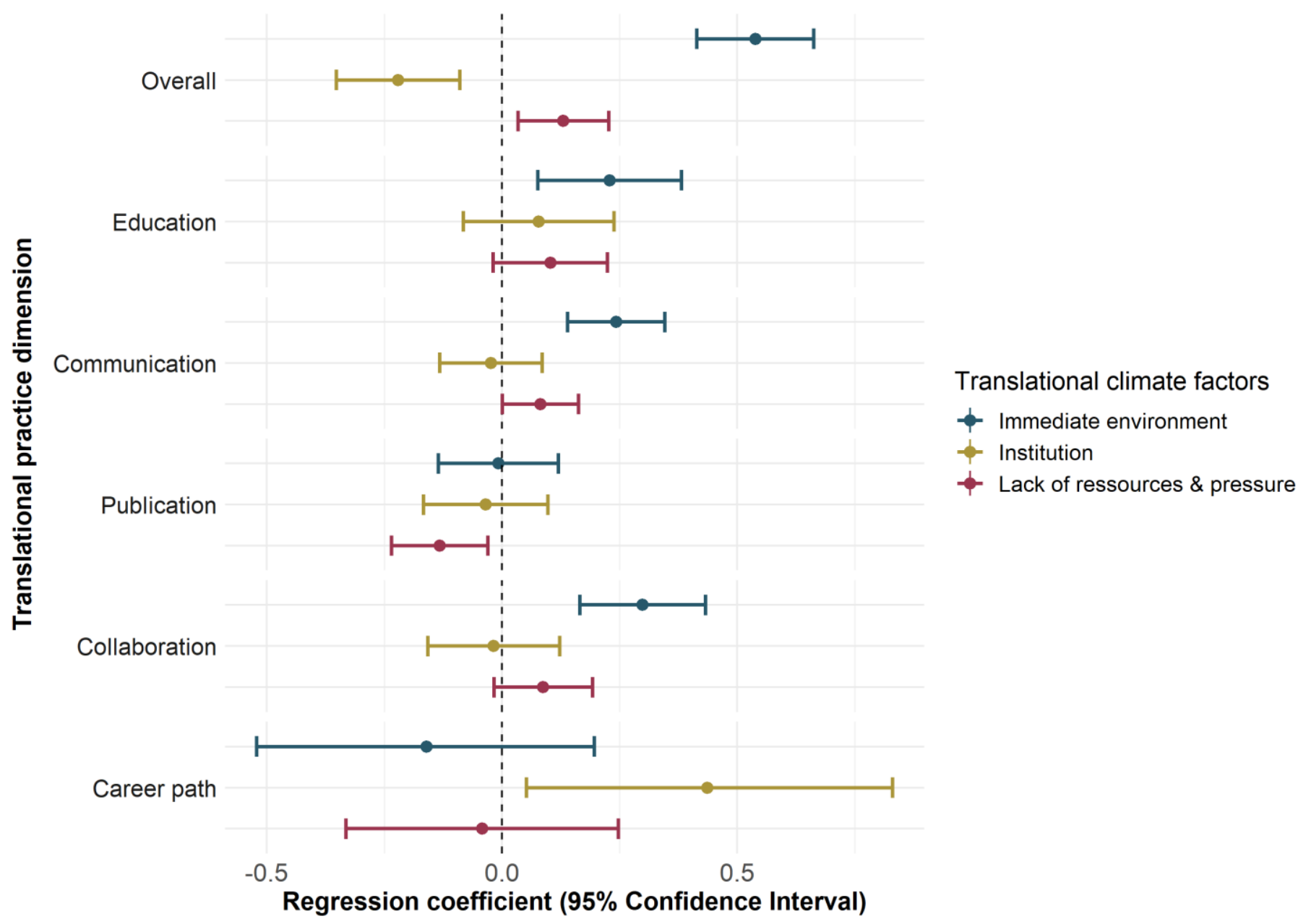

The negative relation between the institutional climate and the overall practice is driven by respondents that give high scores for both the translational climate in the immediate environment and the overall practice but low scores for the translational climate in the institution.

The explained variance was calculated for each of the multiple linear regression models and ranges from $R^{2}=0.18$ for the 'Overall' practice dimension to $\mathrm{R}^{2}=0.02$ for the 'Publication' dimension (supplemental Table S2).

A comparison with the SORC validation results (using the same methods, see supplemental Table S3) [17] gives a similar magnitude of regression coefficients with less of the coefficients being significant - possibly due to the smaller participant number in our study.

The intraclass correlation of the STRC factor scores with respect to the institution's centers shows no substantial variation of score distributions within the different parts of the institution: the ICC is consistent with zero for two STRC factors ('Immediate environment': ICC $=-0.0086,95 \% \mathrm{Cl}[-0.023,0.032]$, 'Lack of resources \& pressure': ICC = - 
$0.0059,95 \% \mathrm{Cl}[-0.024,0.043])$ and negligibly small for the third factor ('Institution': ICC $=0.039,95 \% \mathrm{Cl}[0.0009$, 0.137]). Thus the institution's centers were not included in the regression model.

\section{Discussion}

We presented a new survey for assessing the organizational climate for translational research (STRC), which can be used as a self-assessment tool to assess employees' perceptions of translational research practices and conditions in organizational environments. The Survey of Translational Research Climate (STRC) was modelled after the Survey of Organizational Research Climate (SORC), the latter of which assesses research integrity climate.

We assessed the STRC in a study with 521 respondents from the Charité, which also included the complete original SORC. Firstly, STRC items discriminated into three factors: 1 ) items concerning translational climate in the immediate research environment, 2) items concerning translational climate at the institutional level, and 3) items concerning publishing pressure and the lack of resources. STRC factors 1 and 2 showed good internal validity.

Second, we found that the STRC was clearly distinct from the SORC with an overlap only in two factors. While the two main factors of the STRC remained basically unchanged, two issues - 'pressure to publish \& obtain funding' as well as 'insufficient resources' - turned out to be cross-cutting factors when it came to respondents' assessment of translational as well as research integrity climate. This suggests that these two issues are affecting not only the research integrity climate but also the translational research climate.

Third, we tested the relationship between the three STRC factors and six dimensions derived from additional items assessing the respondents' translational practices. That is, we investigated how perceived climate actually translates into practice. Translational practice across dimensions was mainly determined by the translational climate in the immediate environment. Neither the institutional climate regarding translation nor the lack of resources had strong influences on translational practices.

Several limitations apply. Even though the STRC is distinct from the SORC on most factors, our sample at one institution does not allow a generalization of the identified factors. Tests at additional institutions are necessary to confirm the exploratory results from our study. We ensured robustness of our results within our sample through 
cross-validation of our confirmatory factor analysis. In replications in other institutions this robustness test will reveal whether mapping between factors and questions will be equally stable as in our sample.

Our design tried to maximize response rate by sending reminders, nonetheless, we achieved a suboptimal return rate. An analysis of the demographics of the sample revealed a mixed picture on how representative our sample was for the institution given that we matched the gender ratio, but younger researchers like PhD students were overrepresented in our sample. This may overestimate the effect that we find of the immediate research climate on translational practice. Young researchers are less exposed to institutional structures like research committees and faculty structures, which manifests as a higher rate of 'No basis for judging' answers to the questions on the institutional climate for the youngest age group (supplemental Table S5). One issue that potentially caused the high abortion rate is the limited time researchers have to answer such questionnaires. In future installations, SORC questions should only be included as an additional voluntary set of questions to maximize return for the STRC.

Given our limitations, one result from our study is the positive relationship between immediate research environment and translational practice. That is, for translation to succeed we identified the immediate research environment as an important factor. Interventions that aim at improving the translational climate in the immediate research environment are thus expected to have a positive effect on actual translational practices. Potential interventions based on the literature are investments in research infrastructure and education, incentives for interdisciplinary collaboration and better research quality, standards and guidelines, and more institutional support for bridging agents, such as clinician scientists [19-22].

\section{Acknowledgements}

All of the SORC is used under license granted by Carol R. Thrush, Ed.D. et al. - @ 2006 Carol R. Thrush, Ed.D et al. All rights reserved. No partial reproduction of any portion of SORC shall be made without express consent from the copyright owners.

\section{References}

1. Drolet BC, Lorenzi NM. Translational research: understanding the continuum from bench to bedside. Translational Research. 2011;(157)1:1-5. 
2. Rubio DM, Schoenbaum E, Lee L, Schteingart DE, Marantz PR, Anderson KE, et al. Defining Translational Research: Implications for Training. Acad Med. 2010;(85)3:470-475.

3. Woolf SH. The meaning of translational research and why it matters. JAMA. 2008;(299)2:211-213.Rubio, D.M. et al. Defining Translational Research: Implications for Training. Acad Med 85, 470-475 (2010).

4. Westfall JM, Mold J, Fagnan L. Practice-Based Research-'Blue Highways' on the NIH Roadmap. JAMA. 2007;(297)4:403-406.

5. Sung NS, Crowley Jr WF, Genel M, Salber P, Sandy L, Sherwood LM, et al. Central challenges facing the national clinical research enterprise. Jama. 2003;(289)10:1278-1287.

6. Rubio DM, Robinson G, Giliam VA, Primack BA, Switzer GE, Seltzer DL, et al. Characterization of Investigators' Approach to Translational Research: A Qualitative Study. Clinical and Translational Science. 2014;(7)6:441446.

7. Burke JP, Gitlin LN. How do we change practice when we have the evidence? Am J Occup Ther. 2012;(66)5:e85-88.

8. Hendriks B, Reinhart M. Science Blogs as Critique-Building Public Identities in the Field of Translational Research. Version: 1. SocArXiv [Preprint]. [posted 2018 Sep 24]: [28 p.]. Available from: https://osf.io/preprints/socarxiv/u5erv/.

9. Blümel C, Gauch S, Hendriks B, Krüger AK, Reinhart M. In Search of Translational Research: Report on the Development and Current Understanding of a New Terminology in Medical Research and Practice. Berlin: Institute for Research Information and Quality Assurance, Humboldt-University Berlin; 2015.

10. Blümel C, Gauch S, Krüger AK. Organizing Translational Research: Report on the Establishment, Organization, and Evaluation of the Translational Research Process in leading US Organizations. Berlin: Institute for Research Information and Quality Assurance, Humboldt-University Berlin; 2016.

11. Ehrhart MG, Schneider B, Macey WH. Organizational Climate and Culture: An Introduction to Theory, Research, and Practice. New York: Routledge; 2013.

12. Ashkanasy N, Wilderom CPM, Peterson MF. The Handbook of Organizational Culture and Climate. LA: Sage; 2011. 
13. Reichers AE, Schneider B. Climate and culture: An evolution of constructs. In: Schneider B, editor. Organizational climate and culture. San Francisco: Jossey-Bass; 1990. p. 5-39.

14. Martinson BC, Thrush CR, Crain LA. Development and validation of the Survey of Organizational Research Climate (SORC). Sci Eng Ethics. 2013;(19)3:813-834.

15. Horn JL. A rationale and test for the number of factors in factor analysis. Psychometrika. 1965;(30)2:179185.

16. Benjamini Y, Hochberg Y. Controlling the False Discovery Rate: A Practical and Powerful Approach to Multiple Testing. Journal of the Royal Statistical Society. Series B (Methodological). 1995;(57)1:289-300.

17. Crain AL, Martinson BC, Thrush CR. Relationships between the Survey of Organizational Research Climate (SORC) and self-reported research practices. Sci Eng Ethics. 2013;(19)3:835-850.

18. Wells JA, Thrush CR, Martinson BC, May TA, Stickler M, Callahan EC, et al. Survey of Organizational Research Climates in Three Research Intensive, Doctoral Granting Universities. Journal of Empirical Research on Human Research Ethics. 2014;(9)5:72-88.

19. Daye D, Patel CB, Ahn J, Nguyen FT. Challenges and opportunities for reinvigorating the physician- scientist pipeline. The Journal of clinical investigation. 2015;(125)3:883-887.

20. Glasgow RE, Klesges LM, Dzewaltowski DA, Bull SS, Estabrooks P. The future of health behavior change research: What is needed to improve translation of research into health promotion practice? Ann Behav Med. 2004;(27)1:3-12.

21. Zerhouni EA. Translational Research: Moving Discovery to Practice. Clinical Pharmacology \& Therapeutics. 2007;(81)1:126-128.

22. Zerhouni EA. The NIH roadmap. Science. 2003;(302)5642:63-72.

\section{Supporting information}

S1 Table. Factor analysis using the combined STRC and SORC questionnaires.

ID

$$
\text { Question text }
$$$$
\text { How respectfully do advisors/supervisors treat advisees/supervisees? }
$$

Factor Factor

loading

$1 B 17$
How respectfully do advisors/supervisors treat advisees/supervisees?

1

0.84 

your immediate research environment?

talking with advisees about key principles of research integrity? respect to publishing? obtain permission or give due credit when using another's words or ideas?

environment follow established institutional policies?

1B11 How consistently do responsible individuals in your immediate research environment communicate high expectations for research integrity? maintaining data integrity and data confidentiality? more competitive with one another than they are cooperative? researchers for obtaining external funding?

advisees/supervisees clear performance expectations related to intellectual credit? concern that someone else will 'steal' their ideas? maintaining high standards of translation in their research? environment reflect high values for the translation of research? 
environment communicate high expectations for translational research?

making their findings 'translatable/useful for others'?

talking with advisees about key principles of translational research?

with respect to making your research useful for safe and effective health

measures? practices? performing, and reporting research in your immediate research

\section{environment?} ask for advice if you had a question about research ethics? research misconduct, you would know where to turn to determine what procedures to follow?

1 A07 How accessible are Charité's policies/guidelines that relate to responsible research practices? executive board) communicate high expectations for research integrity? research practices? ask for advice if you had a question about the translation of your research? executive board) to supporting responsible research? 

about responsible research practices (e.g., lectures, seminars, web-based courses)? research useful for safe and effective health measures?

1B18 How true is it that pressure to obtain external funding has a negative effect on the integrity of research in your immediate research environment? of research in your immediate research environment?

2B12 How true is it that pressure to obtain external funding has a negative effect on making your research useful for safe and effective health measures? the translation of research? translation in their research? about translational research practices (e.g., lectures, seminars, web-based courses)? executive board) to supporting translational research?

executive board) communicate high expectations for translational research? access to material resources such as space, equipment, or technology? 
access to human resources such as expertise in research design,

administrative or technical staff within your immediate research

environment?

$1 \mathrm{B04}$

How difficult is it to conduct research in a responsible manner because of

insufficient access to human resources such as statistical expertise,

administrative or technical staff?

$1 \mathrm{~A} 10$

How fair to researchers are the internal regulatory committees or boards

7

0.7

that review the type of research you do (e.g., Ethics Committee,

Forschungskommission, Prodekanat fuer Forschung)?

$1 \mathrm{A03}$

How respectful to researchers are the internal regulatory committees or

boards that review the type of research you do (e.g., Ethics Committee,

Forschungskommission, Prodekanat fuer Forschung)?

$1 \mathrm{~A} 05$

How well do the internal regulatory committees or boards that review your

research (e.g., Ethics Committee, Forschungskommission, Prodekanat fuer

Forschung) understand the kind of research you do?

\section{S2 Table. Regression coefficients for the comparison of the three STRC factors and the predefined six practice}

dimensions. One regression model is calculated per practice dimension with the three STRC factors as predictor. For each regression model the explained variance, F-statistic and corresponding degrees of freedom are given. For each regression coefficient the corresponding t-statistic and p-value are given. There are several significant coefficients (given p-values were corrected using the Benjamini Hochberg procedure), most of them involving the "Immediate environment" factor or the "Overall" practice dimension.

${ }^{\S}$ As the 'Career path' dimension is comprised of 'yes/no' questions, a logistic regression model is used in this case. For this model the McFadden pseudo $\mathrm{R}^{2}$ and the $\chi^{2}$ statistic for the difference between null and residual deviance is used instead.

Education Communication Publication Collaboration Career path Overall 


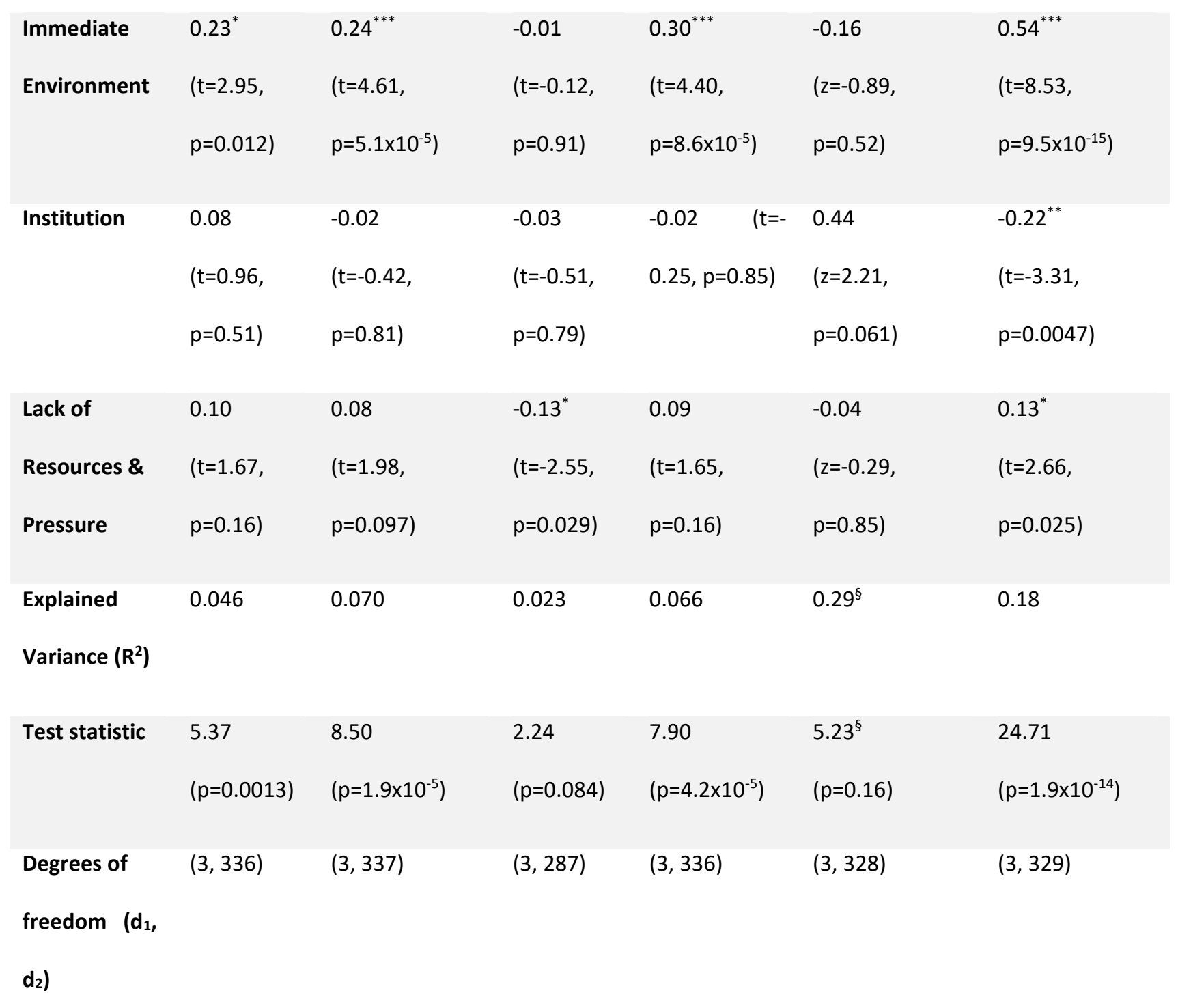

S3 Table. Regression coefficients of the comparison of the three STRC factors and the binary-coded six practice dimensions. There are three significant coefficients ( $* * * p<0.001$ after Holm-Bonferroni correction), all involving the "Immediate environment" factor. Background: To allow for comparison with the results from a study on the relationship between research integrity climate and practice for the SORC survey [17], we repeated their validation analysis for the STRC dataset. For this we transformed the STRC practice dimension scores to a binary scale (analogously to their 'always'/'not always' categorization, we categorizing answers into high/low translational practice, where all scores fall into the high category that are above the median score for this practice dimension). To assess the relationship between the STRC factor scores and the practice dimension scores we fitted a general linear model (GLM) with binomial error and logit for each combination of practice dimension as predictive variable and the binary version of the STRC factor score. To account for the many different models that are tested, resulting $\mathrm{p}$-values 
were corrected using the Benjamini Hochberg procedure [16]. The magnitude of regression coefficients is similar to those for the SORC validation for the "Immediate Environment" factor and smaller for the other two factors. There were much less significant coefficients detected. This might be due to the smaller participant number in our study (521 participant responses used in the regression models compared to 1267 participants for the SORC validation). The binary coding of the practice scores was mainly used to compare the logistic regression coefficients to those presented for the SORC validation. When using the practice scores on their original 1-5 scale (see main text), we obtained the same three strongly significant regression coefficients plus several additional significant coefficients (note that the magnitude of the coefficients is interpreted differently in linear and logistic regression models).

\begin{tabular}{|c|c|c|c|c|c|c|}
\hline & Education & Communication & Publication & Collaboration & $\begin{array}{l}\text { Career } \\
\text { path }\end{array}$ & Overall \\
\hline Immediate & 0.28 & $0.528^{* * *}$ & 0.08 & $0.55^{* * *}$ & 0.011 & $0.81^{* * *}$ \\
\hline \multirow[t]{2}{*}{ Environment } & $(t=2.43$ & $(t=4.06$ & $(t=0.59$ & $(t=4.45$ & $(t=0.08$ & $(t=6.15$ \\
\hline & $p=0.06)$ & $\left.p=2.9 \times 10^{-4}\right)$ & $p=0.67)$ & $\left.p=7.7 \times 10^{-5}\right)$ & $p=0.93)$ & $\left.p=1.4 \times 10^{-8}\right)$ \\
\hline \multirow[t]{3}{*}{ Institution } & 0.22 & $0.349 \quad(t=2.18$ & 0.09 & 0.25 & 0.289 & 0.08 \\
\hline & $(t=1.55$ & $p=0.11)$ & $(t=0.58$ & $(t=1.74$ & $(t=1.78$ & $(t=0.52$ \\
\hline & $\mathrm{p}=0.28)$ & & $p=0.67)$ & $\mathrm{p}=0.21)$ & $\mathrm{p}=0.21)$ & $p=0.68)$ \\
\hline Lack of & 0.08 & 0.126 & -0.08 & -0.11 & -0.114 & -0.02 \\
\hline Resources \& & $(t=0.70$ & $(t=1.02, p=0.61)$ & $(t=-0.67$ & $(t=,-0.92$ & $(t=-0.88$ & $(t=-0.17$ \\
\hline Pressure & $p=0.67)$ & & $p=0.67)$ & $p=0.62)$ & $p=0.62)$ & $p=0.91)$ \\
\hline
\end{tabular}

S4 Table. Summary of the answers to the demographic questions. We could not observe a strong difference between the study population with respect to gender ( $p=0.29$, Fisher's exact test) but we did observe a difference in the age distribution ( $p=1.0 \times 10-7$, Mann-Whitney $U$ test), with especially more survey responses from very young persons ( $<26$ years), which might reflect a high participation rate for doctoral candidates. 


\begin{tabular}{|c|c|c|}
\hline Category & Total & Percentage \\
\hline \multicolumn{3}{|l|}{ Age group } \\
\hline$<26$ & 40 & $7.7 \%$ \\
\hline $26-30$ & 92 & $17.6 \%$ \\
\hline $31-35$ & 87 & $16.7 \%$ \\
\hline $36-40$ & 73 & $14.0 \%$ \\
\hline $41-45$ & 45 & $8.6 \%$ \\
\hline $46-50$ & 43 & $8.2 \%$ \\
\hline $51-55$ & 26 & $5.0 \%$ \\
\hline $56-60$ & 17 & $3.3 \%$ \\
\hline$>60$ & 8 & $1.5 \%$ \\
\hline Prefer not to disclose & 91 & $17.4 \%$ \\
\hline \multicolumn{3}{|l|}{ Gender } \\
\hline Man & 220 & $42.1 \%$ \\
\hline Woman & 259 & $49.6 \%$ \\
\hline Prefer not to disclose & 43 & $8.2 \%$ \\
\hline \multicolumn{3}{|l|}{ Status } \\
\hline Stipend & 34 & $6.5 \%$ \\
\hline Scientific Staff ('WiMi') & 263 & $50.4 \%$ \\
\hline Junior research group leader & 24 & $4.8 \%$ \\
\hline Junior professor & 1 & $0.2 \%$ \\
\hline Professor & 58 & $11.1 \%$ \\
\hline Other & 92 & $17.6 \%$ \\
\hline Prefer not to disclose & 49 & $9.4 \%$ \\
\hline \multicolumn{3}{|l|}{ Doctoral candidate } \\
\hline Yes & 205 & 39.3 \\
\hline No & 290 & 55.6 \\
\hline
\end{tabular}




\begin{tabular}{|c|c|c|}
\hline Prefer not to disclose & 27 & 5.2 \\
\hline \multicolumn{3}{|c|}{ How many years in research } \\
\hline $0-3$ years & 108 & $20.7 \%$ \\
\hline $3-10$ years & 194 & $37.2 \%$ \\
\hline$>10$ years & 206 & $39.5 \%$ \\
\hline Prefer not to disclose & 14 & $2.7 \%$ \\
\hline \multicolumn{3}{|c|}{ How would you describe your } \\
\hline \multicolumn{3}{|l|}{ research? } \\
\hline Preclinical & 188 & $36.1 \%$ \\
\hline Clinical & 135 & $25.9 \%$ \\
\hline Both & 167 & $32.1 \%$ \\
\hline Prefer not to disclose & 31 & $6.0 \%$ \\
\hline
\end{tabular}

S5 Table. Average percentage of 'no basis for judging' answers for the different parts of the questionnaire for all 521 respondents that completed the survey as well as the $\mathbf{4 0}$ respondents with age $<26$ years. The questionnaire categories used are: STRC Institution - Questions 2A01 - 2A06, STRC immediate environment - 2B01 - 2B12, SORC Institution - Questions $1 \mathrm{~A} 03-1 \mathrm{~A} 11$, SORC immediate environment $-1 \mathrm{~B} 03-1 \mathrm{~B} 19$ and $1 \mathrm{~B} 22-1 \mathrm{~B} 23$. For the full questionnaire as well as the question codes see https://osf.io/qak8e/.

$\begin{array}{lllll} & \text { STRC institution } & \begin{array}{l}\text { STRC immediate } \\ \text { environment }\end{array} & \text { SORC institution } & \begin{array}{l}\text { SORC immediate } \\ \text { environment }\end{array} \\ \text { All respondants } & 26.2 \% & 17.0 \% & 17.8 \% & 7.7 \% \\ \text { Age }<26 & 40.8 \% & 30.2 \% & 31.9 \% & 10.9 \%\end{array}$

S1 File. The complete STRC/SORC questionnaire, used to survey scientists at the Charité Berlin. 


\section{The QUEST SOuRCe+ Survey - The organizational climate for responsible and translational research}

Version 1.6/02.02.2018

\section{Dear Participant,}

Thank you very much for your interest in the survey on the organizational climate for responsible and translational research practices at Charité.

This survey is conducted in cooperation with the QUEST Center for Transforming Biomedical Research at the Berlin Institute of Health (BIH) and the German Centre for Higher Education Research and Science Studies (DZHW).

If you agree to participate, please click "continue". With your consent, you allow us to collect, record, analyze and publish your anonymous answers for the purpose of our survey. After completion of the survey, your answers will be completely and forever decoupled from your email address and identity. A cancellation of the anonymity by evaluating the email- or IP-address is technically not possible.

Your participation is voluntary.

Thank you very much.

Sincerely yours

Prof. Dr. Martin Reinhart

\section{Survey}

\section{Part 1 Organizational climate for responsible research practices}

The first part of this survey is designed to assess your view of the organizational climate for responsible research at Charité as a whole and in your immediate research environment (e.g., research group, division, center). Please answer each of the following items with respect to the Charité as a whole (Part 1A). Subsequent questions will ask about your immediate research environment (Part 1B).

\section{Part 1A Charité as a whole}

\begin{tabular}{|l|l|l|}
\hline $\mathbf{1 A 0 1}$ & $\begin{array}{l}\text { How committed are researchers at Charité to maintaining high standards } \\
\text { of integrity in their research? }\end{array}$ & $\begin{array}{l}\text { (1) Not at All } \\
\text { (2) Somewhat } \\
\text { (3) Moderately } \\
\text { (4) Very }\end{array}$ \\
\hline
\end{tabular}




\begin{tabular}{|c|c|c|}
\hline & & $\begin{array}{l}\text { (5) Completely } \\
\text { (9) No Basis for Judging } \\
\text { (10) Prefer not to } \\
\text { disclose }\end{array}$ \\
\hline $1 \mathrm{AO} 2$ & $\begin{array}{l}\text { How consistently does the overall "climate" at Charité reflect high values } \\
\text { for responsible conduct of research? }\end{array}$ & $\begin{array}{l}\text { (1) Not at All } \\
\text { (2) Somewhat } \\
\text { (3) Moderately } \\
\text { (4) Very } \\
\text { (5) Completely } \\
\text { (9) No Basis for Judging } \\
\text { (10) Prefer not to } \\
\text { disclose }\end{array}$ \\
\hline$\underline{1 A 03}$ & $\begin{array}{l}\text { How respectful to researchers are the internal regulatory committees or } \\
\text { boards that review the type of research you do (e.g., Ethics Committee, } \\
\text { Forschungskommission, Prodekanat für Forschung)? }\end{array}$ & $\begin{array}{l}\text { (1) Not at All } \\
\text { (2) Somewhat } \\
\text { (3) Moderately } \\
\text { (4) Very } \\
\text { (5) Completely } \\
\text { (9) No Basis for Judging } \\
\text { (10) Prefer not to } \\
\text { disclose }\end{array}$ \\
\hline$\underline{1 A 04}$ & $\begin{array}{l}\text { How effectively do the available educational opportunities at Charité } \\
\text { teach about responsible research practices (e.g., lectures, seminars, web- } \\
\text { based courses)? }\end{array}$ & $\begin{array}{l}\text { (1) Not at All } \\
\text { (2) Somewhat } \\
\text { (3) Moderately } \\
\text { (4) Very } \\
\text { (5) Completely } \\
\text { (9) No Basis for Judging } \\
\text { (10) Prefer not to } \\
\text { disclose }\end{array}$ \\
\hline$\underline{1 A 05}$ & $\begin{array}{l}\text { How well do the internal regulatory committees or boards that review } \\
\text { your research (e.g., Ethics Committee, Forschungskommission, } \\
\text { Prodekanat für Forschung) understand the kind of research you do? }\end{array}$ & $\begin{array}{l}\text { (1) Not at All } \\
\text { (2) Somewhat } \\
\text { (3) Moderately } \\
\text { (4) Very } \\
\text { (5) Completely }\end{array}$ \\
\hline
\end{tabular}




\begin{tabular}{|c|c|c|}
\hline & & $\begin{array}{l}\text { (9) No Basis for Judging } \\
\text { (10) Prefer not to } \\
\text { disclose }\end{array}$ \\
\hline $1 A 06$ & $\begin{array}{l}\text { How accessible are individuals with appropriate expertise that you could } \\
\text { ask for advice if you had a question about research ethics? }\end{array}$ & $\begin{array}{l}\text { (1) Not at All } \\
\text { (2) Somewhat } \\
\text { (3) Moderately } \\
\text { (4) Very } \\
\text { (5) Completely } \\
\text { (9) No Basis for Judging } \\
\text { (10) Prefer not to } \\
\text { disclose }\end{array}$ \\
\hline$\underline{1 A 07}$ & $\begin{array}{l}\text { How accessible are Charité's policies/guidelines that relate to responsible } \\
\text { research practices? }\end{array}$ & $\begin{array}{l}\text { (1) Not at All } \\
\text { (2) Somewhat } \\
\text { (3) Moderately } \\
\text { (4) Very } \\
\text { (5) Completely } \\
\text { (9) No Basis for Judging } \\
\text { (10) Prefer not to } \\
\text { disclose }\end{array}$ \\
\hline $1 \mathrm{A0}$ & $\begin{array}{l}\text { How committed are the senior administrators at Charité (e.g., deans, } \\
\text { executive board) to supporting responsible research? }\end{array}$ & $\begin{array}{l}\text { (1) Not at All } \\
\text { (2) Somewhat } \\
\text { (3) Moderately } \\
\text { (4) Very } \\
\text { (5) Completely } \\
\text { (9) No Basis for Judging } \\
\text { (10) Prefer not to } \\
\text { disclose }\end{array}$ \\
\hline$\underline{1 A 09}$ & $\begin{array}{l}\text { How effectively do the senior administrators at Charité (e.g., deans, } \\
\text { executive board) communicate high expectations for research integrity? }\end{array}$ & $\begin{array}{l}\text { (1) Not at All } \\
\text { (2) Somewhat } \\
\text { (3) Moderately } \\
\text { (4) Very } \\
\text { (5) Completely }\end{array}$ \\
\hline
\end{tabular}




\begin{tabular}{|c|c|c|}
\hline & & $\begin{array}{l}\text { (9) No Basis for Judging } \\
\text { (10) Prefer not to } \\
\text { disclose }\end{array}$ \\
\hline $1 A 10$ & $\begin{array}{l}\text { How fair to researchers are the internal regulatory committees or boards } \\
\text { that review the type of research you do (e.g., Ethics Committee, } \\
\text { Forschungskommission, Prodekanat für Forschung)? }\end{array}$ & $\begin{array}{l}\text { (1) Not at All } \\
\text { (2) Somewhat } \\
\text { (3) Moderately } \\
\text { (4) Very } \\
\text { (5) Completely } \\
\text { (9) No Basis for Judging } \\
\text { (10) Prefer not to } \\
\text { disclose }\end{array}$ \\
\hline$\underline{1 A 11}$ & $\begin{array}{l}\text { How confident are you that if you needed to report a case of suspected } \\
\text { research misconduct, you would know where to turn to determine what } \\
\text { procedures to follow? }\end{array}$ & $\begin{array}{l}\text { (1) Not at All } \\
\text { (2) Somewhat } \\
\text { (3) Moderately } \\
\text { (4) Very } \\
\text { (5) Completely } \\
\text { (9) No Basis for Judging } \\
\text { (10) Prefer not to } \\
\text { disclose }\end{array}$ \\
\hline $1 A 12$ & $\begin{array}{l}\text { How committed are the senior administrators at Charité (e.g., deans, } \\
\text { executive board) to apply open access in their publication practice? }\end{array}$ & $\begin{array}{l}\text { (1) Not at All } \\
\text { (2) Somewhat } \\
\text { (3) Moderately } \\
\text { (4) Very } \\
\text { (5) Completely } \\
\text { (9) No Basis for Judging } \\
\text { (10) Prefer not to } \\
\text { disclose }\end{array}$ \\
\hline$\underline{1 A 13}$ & $\begin{array}{l}\text { How committed are the senior administrators at Charité (e.g. deans, } \\
\text { executive board) to apply open data principles when publishing research } \\
\text { results? }\end{array}$ & $\begin{array}{l}\text { (1) Not at All } \\
\text { (2) Somewhat } \\
\text { (3) Moderately } \\
\text { (4) Very } \\
\text { (5) Completely }\end{array}$ \\
\hline
\end{tabular}




\begin{tabular}{|l|l|l|}
\hline & & $\begin{array}{l}\text { (9) No Basis for Judging } \\
\text { (10) Prefer not to } \\
\text { disclose }\end{array}$ \\
\hline
\end{tabular}

\section{Part 1B Your Immediate research environment}

In completing the following items, we would like you to think about your immediate research environment (e.g., research group, division, center).

\begin{tabular}{|c|c|c|}
\hline $1 B 01$ & $\begin{array}{l}\text { How committed are people in your immediate research environment to } \\
\text { maintaining high standards of integrity in their research? }\end{array}$ & $\begin{array}{l}\text { (1) Not at All } \\
\text { (2) Somewhat } \\
\text { (3) Moderately } \\
\text { (4) Very } \\
\text { (5) Completely } \\
\text { (9) No Basis for Judging } \\
\text { (10) Prefer not to } \\
\text { disclose }\end{array}$ \\
\hline $1 B 02$ & $\begin{array}{l}\text { How consistently does the overall "climate" in your immediate research } \\
\text { environment reflect high values for the responsible conduct of research? }\end{array}$ & $\begin{array}{l}\text { (1) Not at All } \\
\text { (2) Somewhat } \\
\text { (3) Moderately } \\
\text { (4) Very } \\
\text { (5) Completely } \\
\text { (9) No Basis for Judging } \\
\text { (10) Prefer not to } \\
\text { disclose }\end{array}$ \\
\hline $1 B 03$ & $\begin{array}{l}\text { How fair are your immediate research environment's expectations of } \\
\text { researchers for obtaining external funding? }\end{array}$ & $\begin{array}{l}\text { (1) Not at All } \\
\text { (2) Somewhat } \\
\text { (3) Moderately } \\
\text { (4) Very } \\
\text { (5) Completely } \\
\text { (9) No Basis for Judging } \\
\text { (10) Prefer not to } \\
\text { disclose }\end{array}$ \\
\hline
\end{tabular}




\begin{tabular}{|c|c|c|}
\hline$\underline{1 B 04}$ & $\begin{array}{l}\text { How difficult is it to conduct research in a responsible manner because of } \\
\text { insufficient access to human resources such as statistical expertise, } \\
\text { administrative or technical staff? }\end{array}$ & $\begin{array}{l}\text { (1) Not at All } \\
\text { (2) Somewhat } \\
\text { (3) Moderately } \\
\text { (4) Very } \\
\text { (5) Completely } \\
\text { (9) No Basis for Judging } \\
\text { (10) Prefer not to } \\
\text { disclose }\end{array}$ \\
\hline$\underline{1 B 05}$ & $\begin{array}{l}\text { How fair are your immediate research environment's expectations with } \\
\text { respect to publishing? }\end{array}$ & $\begin{array}{l}\text { (1) Not at All } \\
\text { (2) Somewhat } \\
\text { (3) Moderately } \\
\text { (4) Very } \\
\text { (5) Completely } \\
\text { (9) No Basis for Judging } \\
\text { (10) Prefer not to } \\
\text { disclose }\end{array}$ \\
\hline $1 B 06$ & $\begin{array}{l}\text { How guarded are people in their communications with each other out of } \\
\text { concern that someone else will "steal" their ideas? }\end{array}$ & $\begin{array}{l}\text { (1) Not at All } \\
\text { (2) Somewhat } \\
\text { (3) Moderately } \\
\text { (4) Very } \\
\text { (5) Completely } \\
\text { (9) No Basis for Judging } \\
\text { (10) Prefer not to } \\
\text { disclose }\end{array}$ \\
\hline $1 B 07$ & $\begin{array}{l}\text { How consistently do people in your immediate research environment } \\
\text { obtain permission or give due credit when using another's words or ideas? }\end{array}$ & $\begin{array}{l}\text { (1) Not at All } \\
\text { (2) Somewhat } \\
\text { (3) Moderately } \\
\text { (4) Very } \\
\text { (5) Completely } \\
\text { (9) No Basis for Judging } \\
\text { (10) Prefer not to } \\
\text { disclose }\end{array}$ \\
\hline
\end{tabular}




\begin{tabular}{|c|c|c|}
\hline $1 B 08$ & $\begin{array}{l}\text { How committed are advisors in your immediate research environment to } \\
\text { talking with advisees about key principles of research integrity? }\end{array}$ & $\begin{array}{l}\text { (1) Not at All } \\
\text { (2) Somewhat } \\
\text { (3) Moderately } \\
\text { (4) Very } \\
\text { (5) Completely } \\
\text { (9) No Basis for Judging } \\
\text { (10) Prefer not to } \\
\text { disclose }\end{array}$ \\
\hline$\underline{1 B 09}$ & $\begin{array}{l}\text { How difficult is it to conduct research in a responsible manner because of } \\
\text { insufficient access to material resources such as space, equipment, or } \\
\text { technology? }\end{array}$ & $\begin{array}{l}\text { (1) Not at All } \\
\text { (2) Somewhat } \\
\text { (3) Moderately } \\
\text { (4) Very } \\
\text { (5) Completely } \\
\text { (9) No Basis for Judging } \\
\text { (10) Prefer not to } \\
\text { disclose }\end{array}$ \\
\hline $1 B 10$ & $\begin{array}{l}\text { How effectively are junior researchers socialized about responsible } \\
\text { research practices? }\end{array}$ & $\begin{array}{l}\text { (1) Not at All } \\
\text { (2) Somewhat } \\
\text { (3) Moderately } \\
\text { (4) Very } \\
\text { (5) Completely } \\
\text { (9) No Basis for Judging } \\
\text { (10) Prefer not to } \\
\text { disclose }\end{array}$ \\
\hline $1 B 11$ & $\begin{array}{l}\text { How consistently do responsible individuals in your immediate research } \\
\text { environment communicate high expectations for research integrity? }\end{array}$ & $\begin{array}{l}\text { (1) Not at All } \\
\text { (2) Somewhat } \\
\text { (3) Moderately } \\
\text { (4) Very } \\
\text { (5) Completely } \\
\text { (9) No Basis for Judging } \\
\text { (10) Prefer not to } \\
\text { disclose }\end{array}$ \\
\hline
\end{tabular}




\begin{tabular}{|c|c|c|}
\hline$\underline{1 B 12}$ & $\begin{array}{l}\text { How true is it that pressure to publish has a negative effect on the } \\
\text { integrity of research in your immediate research environment? }\end{array}$ & $\begin{array}{l}\text { (1) Not at All } \\
\text { (2) Somewhat } \\
\text { (3) Moderately } \\
\text { (4) Very } \\
\text { (5) Completely } \\
\text { (9) No Basis for Judging } \\
\text { (10) Prefer not to } \\
\text { disclose }\end{array}$ \\
\hline$\underline{1 B 13}$ & $\begin{array}{l}\text { How consistently do advisors/supervisors communicate to their } \\
\text { advisees/supervisees clear performance expectations related to } \\
\text { intellectual credit? }\end{array}$ & $\begin{array}{l}\text { (1) Not at All } \\
\text { (2) Somewhat } \\
\text { (3) Moderately } \\
\text { (4) Very } \\
\text { (5) Completely } \\
\text { (9) No Basis for Judging } \\
\text { (10) Prefer not to } \\
\text { disclose }\end{array}$ \\
\hline$\underline{1 B 14}$ & How fairly do advisors/supervisors treat advisees/supervisees? & $\begin{array}{l}\text { (1) Not at All } \\
\text { (2) Somewhat } \\
\text { (3) Moderately } \\
\text { (4) Very } \\
\text { (5) Completely } \\
\text { (9) No Basis for Judging } \\
\text { (10) Prefer not to } \\
\text { disclose }\end{array}$ \\
\hline$\underline{1 B 15}$ & $\begin{array}{l}\text { How consistently do research practices in your immediate research } \\
\text { environment follow established institutional policies? }\end{array}$ & $\begin{array}{l}\text { (1) Not at All } \\
\text { (2) Somewhat } \\
\text { (3) Moderately } \\
\text { (4) Very } \\
\text { (5) Completely } \\
\text { (9) No Basis for Judging } \\
\text { (10) Prefer not to } \\
\text { disclose }\end{array}$ \\
\hline
\end{tabular}




\begin{tabular}{|c|c|c|}
\hline$\underline{1 B 16}$ & $\begin{array}{l}\text { How valued is honesty in proposing, performing, and reporting research in } \\
\text { your immediate research environment? }\end{array}$ & $\begin{array}{l}\text { (1) Not at All } \\
\text { (2) Somewhat } \\
\text { (3) Moderately } \\
\text { (4) Very } \\
\text { (5) Completely } \\
\text { (9) No Basis for Judging } \\
\text { (10) Prefer not to } \\
\text { disclose }\end{array}$ \\
\hline$\underline{1 B 17}$ & How respectfully do advisors/supervisors treat advisees/supervisees? & $\begin{array}{l}\text { (1) Not at All } \\
\text { (2) Somewhat } \\
\text { (3) Moderately } \\
\text { (4) Very } \\
\text { (5) Completely } \\
\text { (9) No Basis for Judging } \\
\text { (10) Prefer not to } \\
\text { disclose }\end{array}$ \\
\hline$\underline{1 B 18}$ & $\begin{array}{l}\text { How true is it that pressure to obtain external funding has a negative } \\
\text { effect on the integrity of research in your immediate research } \\
\text { environment? }\end{array}$ & $\begin{array}{l}\text { (1) Not at All } \\
\text { (2) Somewhat } \\
\text { (3) Moderately } \\
\text { (4) Very } \\
\text { (5) Completely } \\
\text { (9) No Basis for Judging } \\
\text { (10) Prefer not to } \\
\text { disclose }\end{array}$ \\
\hline$\underline{1 B 19}$ & $\begin{array}{l}\text { How committed are people in your immediate research environment to } \\
\text { maintaining data integrity and data confidentiality? }\end{array}$ & $\begin{array}{l}\text { (1) Not at All } \\
\text { (2) Somewhat } \\
\text { (3) Moderately } \\
\text { (4) Very } \\
\text { (5) Completely } \\
\text { (9) No Basis for Judging } \\
\text { (10) Prefer not to } \\
\text { disclose }\end{array}$ \\
\hline
\end{tabular}




\begin{tabular}{|c|c|c|}
\hline$\underline{1 B 20}$ & $\begin{array}{l}\text { How committed are researchers in your immediate research environment } \\
\text { to apply open data principles when publishing research results? }\end{array}$ & $\begin{array}{l}\text { (1) Not at All } \\
\text { (2) Somewhat } \\
\text { (3) Moderately } \\
\text { (4) Very } \\
\text { (5) Completely } \\
\text { (9) No Basis for Judging } \\
\text { (10) Prefer not to } \\
\text { disclose }\end{array}$ \\
\hline$\underline{1 B 21}$ & $\begin{array}{l}\text { How committed are researchers in your immediate research environment } \\
\text { to apply open access in their publication practice? }\end{array}$ & $\begin{array}{l}\text { (1) Not at All } \\
\text { (2) Somewhat } \\
\text { (3) Moderately } \\
\text { (4) Very } \\
\text { (5) Completely } \\
\text { (9) No Basis for Judging } \\
\text { (10) Prefer not to } \\
\text { disclose }\end{array}$ \\
\hline$\underline{1 B 22}$ & $\begin{array}{l}\text { How true is it that people in your immediate research environment are } \\
\text { more competitive with one another than they are cooperative? }\end{array}$ & $\begin{array}{l}\text { (1) Not at All } \\
\text { (2) Somewhat } \\
\text { (3) Moderately } \\
\text { (4) Very } \\
\text { (5) Completely } \\
\text { (9) No Basis for Judging } \\
\text { (10) Prefer not to } \\
\text { disclose }\end{array}$ \\
\hline$\underline{1 B 23}$ & How available are advisors/supervisors to their advisees/supervisees? & $\begin{array}{l}\text { (1) Not at All } \\
\text { (2) Somewhat } \\
\text { (3) Moderately } \\
\text { (4) Very } \\
\text { (5) Completely } \\
\text { (9) No Basis for Judging } \\
\text { (10) Prefer not to } \\
\text { disclose }\end{array}$ \\
\hline
\end{tabular}


1 C01 Are there any other things about your organizational climate for

Free text responsible research practices that you would like to tell and about which we have not already asked? 
Part 2 Organizational climate for translational research practice

The second part of this survey is not about responsible research practices but about translational research practices. Not everyone agrees on what the term 'translational' means. When in doubt, please think of practices that help to 'translate' findings in biomedical research into medical practice and meaningful health outcomes (this means, apply findings from biomedical research to medical practice, c.f. 'from bench to bedside'). Please answer each of the following items with respect to the Charite as a whole (Part 2A), your immediate research environment (Part 2B), and your translational practices (Part 2C).

\section{Part 2A Charité as a whole}

\begin{tabular}{|c|c|c|}
\hline $2 A 01$ & $\begin{array}{l}\text { How committed are researchers at Charité to maintaining high standards } \\
\text { of translation in their research? }\end{array}$ & $\begin{array}{l}\text { (1) Not at All } \\
\text { (2) Somewhat } \\
\text { (3) Moderately } \\
\text { (4) Very } \\
\text { (5) Completely } \\
\text { (9) No Basis for Judging } \\
\text { (10) Prefer not to } \\
\text { disclose }\end{array}$ \\
\hline $2 A 02$ & $\begin{array}{l}\text { How consistently does the overall "climate" at Charite reflect high values } \\
\text { for the translation of research? }\end{array}$ & $\begin{array}{l}\text { (1) Not at All } \\
\text { (2) Somewhat } \\
\text { (3) Moderately } \\
\text { (4) Very } \\
\text { (5) Completely } \\
\text { (9) No Basis for Judging } \\
\text { (10) Prefer not to } \\
\text { disclose }\end{array}$ \\
\hline $2 A 03$ & $\begin{array}{l}\text { How effectively do the available educational opportunities at Charité } \\
\text { teach about translational research practices (e.g., lectures, seminars, web- } \\
\text { based courses)? }\end{array}$ & $\begin{array}{l}\text { (1) Not at All } \\
\text { (2) Somewhat } \\
\text { (3) Moderately } \\
\text { (4) Very } \\
\text { (5) Completely } \\
\text { (9) No Basis for Judging } \\
\text { (10) Prefer not to } \\
\text { disclose }\end{array}$ \\
\hline
\end{tabular}




\begin{tabular}{|c|c|c|}
\hline $2 A 04$ & $\begin{array}{l}\text { How accessible are individuals with appropriate expertise that you could } \\
\text { ask for advice if you had a question about the translation of your } \\
\text { research? }\end{array}$ & $\begin{array}{l}\text { (1) Not at All } \\
\text { (2) Somewhat } \\
\text { (3) Moderately } \\
\text { (4) Very } \\
\text { (5) Completely } \\
\text { (9) No Basis for Judging } \\
\text { (10) Prefer not to } \\
\text { disclose }\end{array}$ \\
\hline$\underline{2 A 05}$ & $\begin{array}{l}\text { How committed are the senior administrators at Charité (e.g., deans, } \\
\text { executive board) to supporting translational research? }\end{array}$ & $\begin{array}{l}\text { (1) Not at All } \\
\text { (2) Somewhat } \\
\text { (3) Moderately } \\
\text { (4) Very } \\
\text { (5) Completely } \\
\text { (9) No Basis for Judging } \\
\text { (10) Prefer not to } \\
\text { disclose }\end{array}$ \\
\hline$\underline{2 A 06}$ & $\begin{array}{l}\text { How effectively do the senior administrators at Charité (e.g., deans, } \\
\text { executive board) communicate high expectations for translational } \\
\text { research? }\end{array}$ & $\begin{array}{l}\text { (1) Not at All } \\
\text { (2) Somewhat } \\
\text { (3) Moderately } \\
\text { (4) Very } \\
\text { (5) Completely } \\
\text { (9) No Basis for Judging } \\
\text { (10) Prefer not to } \\
\text { disclose }\end{array}$ \\
\hline
\end{tabular}

Part 2B Your immediate research environment

\begin{tabular}{|c|c|c|}
\hline $2 B 01$ & $\begin{array}{l}\text { How committed are people in your immediate research environment to } \\
\text { maintaining high standards of translation in their research? }\end{array}$ & $\begin{array}{l}\text { (1) Not at All } \\
\text { (2) Somewhat } \\
\text { (3) Moderately } \\
\text { (4) Very } \\
\text { (5) Completely }\end{array}$ \\
\hline
\end{tabular}




\begin{tabular}{|c|c|c|}
\hline & & $\begin{array}{l}\text { (9) No Basis for Judging } \\
\text { (10) Prefer not to } \\
\text { disclose }\end{array}$ \\
\hline$\underline{2 B 02}$ & $\begin{array}{l}\text { How consistently does the overall "climate" in your immediate research } \\
\text { environment reflect high values for the translation of research? }\end{array}$ & $\begin{array}{l}\text { (1) Not at All } \\
\text { (2) Somewhat } \\
\text { (3) Moderately } \\
\text { (4) Very } \\
\text { (5) Completely } \\
\text { (9) No Basis for Judging } \\
\text { (10) Prefer not to } \\
\text { disclose }\end{array}$ \\
\hline$\underline{2 B 03}$ & $\begin{array}{l}\text { How difficult is it to conduct translational research because of insufficient } \\
\text { access to human resources such as expertise in research design, } \\
\text { administrative or technical staff within your immediate research } \\
\text { environment? }\end{array}$ & $\begin{array}{l}\text { (1) Not at All } \\
\text { (2) Somewhat } \\
\text { (3) Moderately } \\
\text { (4) Very } \\
\text { (5) Completely } \\
\text { (9) No Basis for Judging } \\
\text { (10) Prefer not to } \\
\text { disclose }\end{array}$ \\
\hline$\underline{2 B 04}$ & $\begin{array}{l}\text { How reasonable are your immediate research environment's expectations } \\
\text { with respect to making your research useful for safe and effective health } \\
\text { measures? }\end{array}$ & $\begin{array}{l}\text { (1) Not at All } \\
\text { (2) Somewhat } \\
\text { (3) Moderately } \\
\text { (4) Very } \\
\text { (5) Completely } \\
\text { (9) No Basis for Judging } \\
\text { (10) Prefer not to } \\
\text { disclose }\end{array}$ \\
\hline$\underline{2 B 05}$ & $\begin{array}{l}\text { How committed are people in your immediate research environment to } \\
\text { making their findings 'translatable/useful for others'? }\end{array}$ & $\begin{array}{l}\text { (1) Not at All } \\
\text { (2) Somewhat } \\
\text { (3) Moderately } \\
\text { (4) Very } \\
\text { (5) Completely }\end{array}$ \\
\hline
\end{tabular}




\begin{tabular}{|c|c|c|}
\hline & & $\begin{array}{l}\text { (9) No Basis for Judging } \\
\text { (10) Prefer not to } \\
\text { disclose }\end{array}$ \\
\hline $2 \mathrm{~B} 06$ & $\begin{array}{l}\text { How committed are advisors in your immediate research environment to } \\
\text { talking with advisees about key principles of translational research? }\end{array}$ & $\begin{array}{l}\text { (1) Not at All } \\
\text { (2) Somewhat } \\
\text { (3) Moderately } \\
\text { (4) Very } \\
\text { (5) Completely } \\
\text { (9) No Basis for Judging } \\
\text { (10) Prefer not to } \\
\text { disclose }\end{array}$ \\
\hline $2 \mathrm{BO} 07$ & $\begin{array}{l}\text { How difficult is it to conduct translational research because of insufficient } \\
\text { access to material resources such as space, equipment, or technology? }\end{array}$ & $\begin{array}{l}\text { (1) Not at All } \\
\text { (2) Somewhat } \\
\text { (3) Moderately } \\
\text { (4) Very } \\
\text { (5) Completely } \\
\text { (9) No Basis for Judging } \\
\text { (10) Prefer not to } \\
\text { disclose }\end{array}$ \\
\hline $2 B 08$ & $\begin{array}{l}\text { How effectively are junior researchers socialized in translational research } \\
\text { practices? }\end{array}$ & $\begin{array}{l}\text { (1) Not at All } \\
\text { (2) Somewhat } \\
\text { (3) Moderately } \\
\text { (4) Very } \\
\text { (5) Completely } \\
\text { (9) No Basis for Judging } \\
\text { (10) Prefer not to } \\
\text { disclose }\end{array}$ \\
\hline $2 \mathrm{BO} 09$ & $\begin{array}{l}\text { How consistently do responsible individuals in your immediate research } \\
\text { environment communicate high expectations for translational research? }\end{array}$ & $\begin{array}{l}\text { (1) Not at All } \\
\text { (2) Somewhat } \\
\text { (3) Moderately } \\
\text { (4) Very } \\
\text { (5) Completely }\end{array}$ \\
\hline
\end{tabular}




\begin{tabular}{|c|c|c|}
\hline & & $\begin{array}{l}\text { (9) No Basis for Judging } \\
\text { (10) Prefer not to } \\
\text { disclose }\end{array}$ \\
\hline $2 B 10$ & $\begin{array}{l}\text { How true is it that pressure to publish has a negative effect on making } \\
\text { your research useful for safe and effective health measures? }\end{array}$ & $\begin{array}{l}\text { (1) Not at All } \\
\text { (2) Somewhat } \\
\text { (3) Moderately } \\
\text { (4) Very } \\
\text { (5) Completely } \\
\text { (9) No Basis for Judging } \\
\text { (10) Prefer not to } \\
\text { disclose }\end{array}$ \\
\hline 2B11 & $\begin{array}{l}\text { How valued is envisioning safe and effective health measures in } \\
\text { proposing, performing, and reporting research in your immediate } \\
\text { research environment? }\end{array}$ & $\begin{array}{l}\text { (1) Not at All } \\
\text { (2) Somewhat } \\
\text { (3) Moderately } \\
\text { (4) Very } \\
\text { (5) Completely } \\
\text { (9) No Basis for Judging } \\
\text { (10) Prefer not to } \\
\text { disclose }\end{array}$ \\
\hline $2 B 12$ & $\begin{array}{l}\text { How true is it that pressure to obtain external funding has a negative } \\
\text { effect on making your research useful for safe and effective health } \\
\text { measures? }\end{array}$ & $\begin{array}{l}\text { (1) Not at All } \\
\text { (2) Somewhat } \\
\text { (3) Moderately } \\
\text { (4) Very } \\
\text { (5) Completely } \\
\text { (9) No Basis for Judging } \\
\text { (10) Prefer not to } \\
\text { disclose }\end{array}$ \\
\hline
\end{tabular}




\begin{tabular}{|c|c|c|}
\hline$\underline{2 C 01}$ & Do you consider your own work translational? & $\begin{array}{l}\text { (1) Not at All } \\
\text { (2) Somewhat } \\
\text { (3) Moderately } \\
\text { (4) Very } \\
\text { (5) Completely } \\
\text { (9) No Basis for Judging } \\
\text { (10) Prefer not to } \\
\text { disclose }\end{array}$ \\
\hline$\underline{2 \mathrm{CO} 2}$ & Overall, do you think translation is a relevant issue? & $\begin{array}{l}\text { (1) Not at All } \\
\text { (2) Somewhat } \\
\text { (3) Moderately } \\
\text { (4) Very } \\
\text { (5) Completely } \\
\text { (9) No Basis for Judging } \\
\text { (10) Prefer not to } \\
\text { disclose }\end{array}$ \\
\hline$\underline{2 \mathrm{CO} 3}$ & $\begin{array}{l}\text { Since finishing your university education, how often have you acquired } \\
\text { knowledge and skills beyond your main field of expertise (e.g., through } \\
\text { continuous education, professional training, online courses, field visits) }\end{array}$ & $\begin{array}{l}\text { (1) Never } \\
\text { (2) Rarely } \\
\text { (3) Sometimes } \\
\text { (4) Very Often } \\
\text { (5) Always } \\
\text { (10) Prefer not to } \\
\text { disclose }\end{array}$ \\
\hline$\underline{2 \mathrm{CO} 4}$ & $\begin{array}{l}\text { How often do you read journals/magazines from outside of your main } \\
\text { field of expertise? }\end{array}$ & $\begin{array}{l}\text { (1) Never } \\
\text { (2) Rarely } \\
\text { (3) Sometimes } \\
\text { (4) Very Often } \\
\text { (5) Always } \\
\text { (10) Prefer not to } \\
\text { disclose }\end{array}$ \\
\hline
\end{tabular}




\begin{tabular}{|c|c|c|}
\hline$\underline{2 C 05}$ & $\begin{array}{l}\text { How many of your publications are in journals/magazines from outside of } \\
\text { your main field of expertise? }\end{array}$ & $\begin{array}{l}\text { (1) None of my } \\
\text { publications } \\
\text { (2) Less than half of my } \\
\text { publications } \\
\text { (3) About half of my } \\
\text { publications } \\
\text { (4) More than half of my } \\
\text { publications } \\
\text { (5) All my publications } \\
\text { (9) Does not apply } \\
\text { (10) Prefer not to } \\
\text { disclose }\end{array}$ \\
\hline$\underline{2 C 06}$ & $\begin{array}{l}\text { How many of your publications have you made freely accessible to } \\
\text { everyone? }\end{array}$ & $\begin{array}{l}\text { (1) None of my } \\
\text { publications } \\
\text { (2) Less than half of my } \\
\text { publications } \\
\text { (3) About half of my } \\
\text { publications } \\
\text { (4) More than half of my } \\
\text { publications } \\
\text { (5) All my publications } \\
\text { (9) Does not apply } \\
\text { (10) Prefer not to } \\
\text { disclose }\end{array}$ \\
\hline$\underline{2 C O 7}$ & How often do you make your data freely accessible to everyone? & $\begin{array}{l}\text { (1) Never } \\
\text { (2) Rarely } \\
\text { (3) Sometimes } \\
\text { (4) Very Often } \\
\text { (5) Always } \\
\text { (9) Does not apply } \\
\text { (10) Prefer not to } \\
\text { disclose }\end{array}$ \\
\hline$\underline{2 C 08}$ & How often do you use data made freely accessible by others? & $\begin{array}{l}\text { (1) Never } \\
\text { (2) Rarely } \\
\text { (3) Sometimes } \\
\text { (4) Very Often } \\
\text { (5) Always }\end{array}$ \\
\hline
\end{tabular}




\begin{tabular}{|c|c|c|}
\hline & & $\begin{array}{l}\text { (10) Prefer not to } \\
\text { disclose }\end{array}$ \\
\hline$\underline{2 C 09}$ & $\begin{array}{l}\text { How often do you provide expertise to people from other fields of } \\
\text { expertise? }\end{array}$ & $\begin{array}{l}\text { (1) Never } \\
\text { (2) Rarely } \\
\text { (3) Sometimes } \\
\text { (4) Very Often } \\
\text { (5) Always } \\
\text { (10) Prefer not to } \\
\text { disclose }\end{array}$ \\
\hline$\underline{2 C 10}$ & $\begin{array}{l}\text { How often do you seek expertise from people from other fields of } \\
\text { expertise? }\end{array}$ & $\begin{array}{l}\text { (1) Never } \\
\text { (2) Rarely } \\
\text { (3) Sometimes } \\
\text { (4) Very Often } \\
\text { (5) Always } \\
\text { (10) Prefer not to } \\
\text { disclose }\end{array}$ \\
\hline$\underline{2 C 11}$ & How often do you collaborate with people from other fields of expertise? & $\begin{array}{l}\text { (1) Never } \\
\text { (2) Rarely } \\
\text { (3) Sometimes } \\
\text { (4) Very Often } \\
\text { (5) Always } \\
\text { (10) Prefer not to } \\
\text { disclose }\end{array}$ \\
\hline$\underline{2 C 12}$ & How often are you involved in interdisciplinary projects? & $\begin{array}{l}\text { (1) Never } \\
\text { (2) Rarely } \\
\text { (3) Sometimes } \\
\text { (4) Very Often } \\
\text { (5) Always } \\
\text { (10) Prefer not to } \\
\text { disclose }\end{array}$ \\
\hline
\end{tabular}




\begin{tabular}{|l|l|l|}
\hline$\underline{\mathbf{2 C 1 3}}$ & During your career, have you ever switched fields? & $\begin{array}{l}\text { yes/no } \\
\text { (10) Prefer not to } \\
\text { disclose }\end{array}$ \\
\hline$\underline{\mathbf{2 C 1 4}}$ & During your career, have you ever switched between lab and clinic? & $\begin{array}{l}\text { yes/no } \\
\text { (10) Prefer not to } \\
\text { disclose }\end{array}$ \\
\hline$\underline{\mathbf{2 C 1 5}}$ & $\begin{array}{l}\text { Are there any other things about the overall organizational climate for } \\
\text { translational research practices that you would like to tell and about } \\
\text { which we have not already asked? }\end{array}$ & \begin{tabular}{l} 
Free Text \\
\hline
\end{tabular}
\end{tabular}

\section{Concluding question of Part 2}

\begin{tabular}{|l|l|l|}
\hline$\underline{\text { 2D01}}$ & $\begin{array}{l}\text { Are there any other things about your experience with translational } \\
\text { research practices at the Charité that you would like to tell and about } \\
\text { which we have not already asked? }\end{array}$ & Free Text \\
\hline
\end{tabular}

Part 3 Demographic information

\begin{tabular}{|c|c|c|}
\hline$\underline{3 A 01}$ & In what year were you born? & $\begin{array}{l}\text { YYYY } \\
\text { [] Prefer not to disclose }\end{array}$ \\
\hline$\underline{3 A 02}$ & How do you identify your gender? & $\begin{array}{l}\text { [] Man } \\
\text { [] Woman } \\
\text { [] Other } \\
\text { []__ (fill in the blank) } \\
\text { [] Prefer not to disclose }\end{array}$ \\
\hline$\underline{3 A 03}$ & What is your current status at Charité? & $\begin{array}{l}\text { [] Stipend } \\
\text { [] Scientific Staff ("WiMi") }\end{array}$ \\
\hline
\end{tabular}




\begin{tabular}{|c|c|c|}
\hline & & $\begin{array}{l}\text { [] Junior professor } \\
\text { [] Professor } \\
\text { [] Other (e.g. doctoral candidate } \\
\text { without contract) } \\
\text { [] Prefer not to disclose }\end{array}$ \\
\hline$\underline{3 A 04}$ & What is your primary departmental affiliation? & $\begin{array}{l}\text { Charite > Pulldown } 15 \\
\text { ChariteCentren } \\
\text { [] Prefer not to disclose }\end{array}$ \\
\hline$\frac{3 A 05}{\underline{a}}$ & Are you a doctoral candidate? & $\begin{array}{l}\text { [] yes } \\
\text { [] no } \\
\text { [] Prefer not to disclose }\end{array}$ \\
\hline$\frac{3 A 05}{\underline{b}}$ & If yes in III.1e: in which doctoral program? & $\begin{array}{l}\text { [] Dr. med. } \\
\text { [] Dr. med. dent. } \\
\text { [] Dr. rer. medic. } \\
\text { [] Dr. rer. cur. } \\
\text { [] PhD } \\
\text { [] MD/PhD } \\
\text { [] Prefer not to disclose }\end{array}$ \\
\hline$\underline{3 A 06}$ & How many years are you working in research? & $\begin{array}{l}\text { [] 0-3 years } \\
\text { [] 3-10 years } \\
\text { [] }>10 \text { years } \\
\text { [] Prefer not to disclose }\end{array}$ \\
\hline$\underline{3 A 07}$ & How would you describe your research? & $\begin{array}{l}\text { [] preclinical } \\
\text { [] clinical } \\
\text { [] both } \\
\text { [] Prefer not to disclose }\end{array}$ \\
\hline$\underline{3 A 08}$ & Are you a clinician scientist? & $\begin{array}{l}\text { [] yes } \\
\text { [] no } \\
\text { [] Prefer not to disclose }\end{array}$ \\
\hline$\underline{3 A 09}$ & What research area best describes your research? & Pulldown selected DFG areas \\
\hline
\end{tabular}




\begin{tabular}{|l|l|l|}
\hline $\mathbf{3 A 1 0}$ & $\begin{array}{l}\text { Size of the immediate research environment you referred to in } \\
\text { the questions above. }\end{array}$ & $\begin{array}{l}\text { [] Prefer not to disclose } \\
\text { [] 11-20 people } \\
\text { [] 21-50 people } \\
\text { [] 50-100 people } \\
\text { [] 100+ people } \\
\text { [] Prefer not to disclose }\end{array}$ \\
\hline$\underline{\mathbf{3 A 1 1}}$ & $\begin{array}{l}\text { Please choose which institution you would like to give your } \\
\text { donation. }\end{array}$ & $\begin{array}{l}\text { [] Deutsche Krebsstiftung } \\
\text { [] Open Science Foundation } \\
\text { [] at random }\end{array}$ \\
\hline
\end{tabular}

Thank you very much for your participation. 